\title{
EXHIBITIONARY COMPLEX: ARCHITECTURE AS AN EXHIBIT
}

\author{
A $B$ S S T R A
}

Within this research, the exhibitions are considered primarily as institutions, and as a place of interaction among different identities through choice of exhibits, their presentation, spatial layout and the selection and use of the accompanying texts. The context of the research thus put into place will attempt to answer the question of how it is possible to construct a history of the exhibitions - which are forgotten, often without sufficient documentation or records about them. In addition, it will be reconsidered in which manner the exhibitions helped to create and promote the idea of architecture during the $20^{\text {th }}$ century, overlapping with the shifting of discourses, broader philosophical debates and technological innovations. 
DEFINING THE PHENOMENON OF EXHIBITION:

FROM THE CABINET DES CURIOSITÉS TO THE SPACE FOR CREATING AN IMAGE OF CULTURE

This research is directed towards identification and defining of the potential of exhibitions to reflect changes of historical, political and cultural events, as well as to function as places for promoting the discussions on relevant social and cultural issues. Having that as a goal, as a starting point, the first part deals with basic concepts for defining exhibition, and in that way at the very beginning of the study, the theoretical and practical field of research has been clearly determined within which the approach to the theme of exhibitions and their relationship to the field of architecture has been positioned.

\section{Exhibitions: the Cultural Practice between the Criticism and Spectacle}

Interpretations of the concept of exhibition can be numerous, depending on the context within which the given term is interpreted. Since this is a complex social phenomenon, depending on the way of observation, the exhibition is determined in a double way, as an act of "public display" (works of art, manufactured goods, items from nature, etc.) and as "the place where the display occurs." Defined in this way, exhibition simultaneously exists as an event and space, i.e. as action and place (location) ${ }^{2}$. Considered as an event, exhibitions are almost always a set of psychological, aesthetic and ideological accumulations ${ }^{3}$, and thus can be interpreted and understood only if they are perceived and reflected in the form of social events. Considered as the place, exhibition areas are full of discourse - the exhibition is not only what appears to the eye, it not only means a superficial image or representation, but also includes a set of ideas, languages and mechanisms through which it materializes, using mostly the world of art and culture as the mechanism of production of meaning and sense $\mathrm{e}^{4}$.

The contemporary concept of exhibitions as the time limited display of art and other artifacts in public was formed in the $18^{\text {th }}$ century. Before that, the majority of art objects of the sacral character were a part of the private collections and available only to a narrow circle of visitors who most often belonged to the social élite of that time..$^{5}$ In the mid $18^{\text {th }}$ century there came to the changes in the form of organization of the first displays of such object in public - i.e. the exhibitions. ${ }^{6}$ Since then, after the exhibitions had ceased to be aimed only for the members of the academic community and the social élite, there came to the change in reception and production of art and artworks in general and the 
exhibitions, being a form of public presentation and display, gradually gained in significance and became an inseparable part of the social events.

The question of "publicity" is of great significance for defining the comprehension of exhibition. In order for a certain event to be clasified as an exhibition, it is necessary to be regarded as public, i.e. to make it available for viewing of a certain number of visitors. ${ }^{7}$ Without the presumption of the publicity, the exhibitions could not exist and most likely would not possess the equal social significance they nowaday have. Based on the previously stated, a conclusion can be drawn that exhibitions, as collections of objects, attained their full potential only when they became part of the public sphere, that is, only then when it was made possible for the general public to become familiar with their contents. Therefore, the exhibition - as a model - always presumes the existence of a certain object or collection of objects and their public presentation.

Considering that creation of exhibitions can be perceived through application of certain cultural patterns that create a link between the exhibited work and the visitors (general public) by studying the exhibitions as models of public presentation it is possible to show how there comes to transformation of the meaning and sense in culture. If the history of exhibitions is analyzed as a model within which the production of meaning and transformations in cultures are followed, depending on the context, it can be determined that the exhibitions do not comprise the closed and complete systems ${ }^{8}$, and that their meaning and valuation change, expand and invert in line with the manner of conceptualization of reality in time and space within which the given exhibition is interpreted. ${ }^{9}$ Thereby, it is rather difficult to make an unambiguous and final definition of the phenomenon of exhibition, first of all, because it is almost impossible to determine with one notion all that which an exhibition actually represents. The possibility and necessity of multifold interpretation of exhibitions is also confirmed by Walter Benjamin when speaking about the difference between the exhibition-value and the cult-value of these manifestations. ${ }^{10}$ This distinction, certainly, is associated with the difference in the meaning of the terms vorstellen and herstellen, to exhibit and to construct, originating from the German language, used by Heideger when speaking about the exhibitions in his lectures on the origin of the artwork. ${ }^{11}$

In the multiplicity of diverse determinations one of the definitions of the exhibitions provided by Ivo Maroević states that exhibitions are "an event in which the society and time meet and connect in space". ${ }^{12}$ According to 
this definition, the exhibition has been determined as an event, while at the same time exhibitions may be defined also as the place/location where public opinion is "produced" and "constituted", but also where the exchange of certain (social) values and powers takes place. ${ }^{13}$ Miško Šuvaković generally agrees with this definition and additionally specifies exhibitions as a spectacle within which "the spectacularity has materially been performed as a live event of presentation and sensual transferability of "power" in everyday life of the society". ${ }^{14}$ When speculating about the notion of exhibition Šuvaković writes also about the ideological aspect of each exhibition for which he states:

"Ideology of the exhibition is not a set of orientated completely rational intentions of the organizer (curator, author of the conception, financier, cultural workers, politicians). Ideology is an uncertain atmosphere (environment) of conceptualized and non-conceptualized possibilities, resolutions, symbolizations, decisions, proclamations, neglect (deletion), random choices, selections, proposals, values, tacit knowledge, censures, effects of the public and private taste, excuses, wishes and social functions which construct some reality of exhibition acceptable for the society and culture". ${ }^{15}$

Further on, Šuvaković states that:

"Ideology of an exhibition or family of exhibitions is not that order (text) of the messages which the authors of the exhibition project and proclaim through their introductory and accompanying texts, but that difference of the intended and unintended, acceptable and unacceptable in respect to the public and tacit scenes: of the conscious and the unconscious, namely, the literal and fictional". ${ }^{16}$

According to Šuvaković, ideology of the exhibition is not that which is intended for the acceptance by the public opinion (doxa), but that which paradoxically forms doxa and represents its expression (the individual example) in some exchange of the "social values" and "social powers". ${ }^{17}$ The definition of the exhibition as the place of exchange is agreed also by the editors of the book "Thinking about Exhibition" who state that: "Exhibitions are primarily the places of exchange in the political economy of art, where the significance is constructed, maintained and occasionally deconstructed. Partly spectacle, partly social-historical event (fact), partly the tool of structuring, the exhibitions establish and frame the culturological meaning of art" ${ }^{18}$ Exhibitions as places of spectacle and exchange of social values and power were represented also by Walter Benjamin. In the study of the World exhibitions, Benjamin defines the exhibitions as spectacles whose aim was to glorify the manufacturing value of goods and to provide the frame within which consumer culture would be promoted. ${ }^{19}$ 
Also, exhibitions can be defined as phenomena limited in terms of space and time. ${ }^{20}$ In such perspective, an exhibition is perceived as a summary of visible and written parts, simultaneously the public presentation and reception (definition rooted in the very etymology of the word) which most often comes to us from the past by means of photographs, catalogues and other archived documents. Thus, very often, the exhibition has a direct effect upon its visitors, by means of another medium or even in some other time, which does not diminish the power and significance of its message. Still, unlike its historical predecessors, contemporary exhibitions possess more influential even though not completely clarified potentials - both for the art practice, and for the more successful interpretation of art and visual paradigms.

\section{Exhibition: Medium, Institution and Artistic Form}

The privileged position of the exhibition in the center of cultural events has a great influence and significance upon definition of this term. However, at the same time there is not one unique definition that specifies exhibition completely. In the course of time, as the exhibitions evolved and as their role in the society changed, so did also the ways of its (exhibition) interpretation. Currently it is possible to interpret the exhibition in three ways, by means of three aspects: as a medium, as an institution and as an independent art form.

Primarily the exhibition was understood as the act of communication between the artist and his/her public (in layman's terms and the professional one). Set in the center of all activities, at the intersections of different fields, the exhibition represents a summary and the final product of diverse volitions and influences, and is used mostly for presentation of certain ideas, meanings and values. However, the exhibition medium very often determines and is determined by other media: the architecture of the exhibition space, lighting, color, printed matter and catalogues and the very exhibitionary items. ${ }^{21}$ In the end it forms a strategic system of representation which shapes the culturological meaning and reception of the displayed artifacts. As such, the exhibition is in the position to generate comprehension of art in certain time and at certain place.

Exhibitions as an institution synthesize the process of identification, selection, promotion and post-production of the objects into artworks (in architecture the public recognition of certain object or design as successful). In spite of the absence of objective criteria for valuation, the exhibition provides space for identification and recognition of artworks, the artists and curators, since it forms the final framework, the omnipresent medium through which the works pass in order to become art. 
Through time, the exhibitions have surpassed the task of displaying art and became transformed into independent systems of (re)presentation, interpretation and reflection. Owing to the possibility to form new activities and visual discourses, the exhibitions can be perceived as an independent art form possessing its art values. In this case, the exhibition exceeds the task of sheer displaying and becomes transformed into independent system of presenting, discourse, interpretation and reflection. Due to the ability of the independent creation of new activities and the modality of visual, the exhibitions have acquired the art value. ${ }^{22}$

The complexity of the notion of exhibition and its development as an independent manifestation have influenced forming of the idea on much more efficient and effective organization, selection and promotion of exhibitions. Also, an idea has been formed on historical, thematic interpretation and classification of exhibitions. When speaking of classification of exhibitions, Miško Šuvaković in his Glossary of Contemporary Art defines the exhibitions as a form of presentation of the artwork in gallery or museum space, whereas in the conceptual sense by using this definition one can differentiate: independent exhibitions (single work or larger opus), group exhibitions (the works of a group of authors who are not associated obligatory or are associated as per the theme and/or concept), author exhibitions (the topical problem of art is presented) and the exhibitions as the artwork. $^{23}$

\section{Historical Development of Exhibitions}

The phenomenon of exhibition is associated with formation of the civil society in the period of the late $17^{\text {th }}$ and the beginning of the $18^{\text {th }}$ century, when there comes to transformation of the act of presentation of work (until then reserved for the élite) to the wider audience. ${ }^{24}$ The first and the most prominent institution which started with the practice of public display of the works ${ }^{25}$ intended for the broader audience was the Paris Salon (Salon de Paris), which has been held since $1737 .{ }^{26}$ The Salon was established as a regular exhibition of the members of the French academy with an aim to bring the art closer to the general public and with a long-term goal that "good art" (sometimes academic, and presently modern and contemporary) is imposed as the only representative of the citizens, namely as the expression of the political power of the people. ${ }^{27}$ From the very beginning, the Salon represented an institution made of a complex system of different opinions and interests, among which the process and mechanism of participant selection was in the forefront, and which was based on the jury decisions and the Salon critics. The critics and jury functioned as a mediator 
and corrector of the ideological and political goals. ${ }^{28}$ Having in view that the criteria according to which the participants were selected were founded equally on the political as much as on the aesthetic criteria, it is clear that the Salon participants were more delegates than representatives of the art world, which favored the fact that the Salon has always represented the elitist institution. ${ }^{29}$

Following the Paris Salon, there were great number of exhibitions established, i.e. collections of art objects which were exhibited for the public viewing. At first, the exhibitions represented exactly that: assortment, collection or a great number of art objects in one place. Since the very first exhibitions did not possess a special system of showing or genre differentiation, in a majority of cases they consisted of a great number of exhibits placed without any obvious order or sequence. However, since the basis of each collection was to "describe, classify" 30 and continuously re-construct the world, as a materialization about what it looks like, how it is established and who controls it $^{31}$ in time there emerged an idea on a special manner of organization and presentation of the exhibits. In the second half of the $19^{\text {th }}$ century there came to the change in awareness about the relationship between the observer/visitor and the work displayed, i.e. collection, as well as in which ways this relationship could be influenced. Initially, the exhibition is considered as assortment, collection, collected material through which assemblage of the exhibition is constructed and emphasizes the meaning of the objects displayed and structures the experience of the visitor, i.e. observer. ${ }^{32}$ When considering the notion of the collection within the book "On politics of identities and other museum stories" (О политикама идентитета и друге музејске приче), Ljiljana Gavrilović writes that:

"Each collection of (items, thoughts, ideas - one always implies the other) possesses two basic characteristics. It is conceptualized in compliance with the idea of the collector what is valuable and what it wishes to say/show, and at the same time it is what anyone, from those communicating with it, think it is. This naturally means that the collector and the observer (the one who reads/interprets the collection outward) may have completely different perceptions of the value/ meaning of the entire collection, as well as some of its parts/elements. The relationship of the collector and the observer in respect to the collected material, organized in any type of the collection, is always the inside:outward relationship, defined by boundaries". ${ }^{33}$

Further on, Gavrilović defines those boundaries as real (that which actually exists within the collection) and/or ideal (that which should exist within it). Then, further on she considers them as variable and dependent on the context within which the collection originated, as well as on the discourse 
of the collector and the observer. Considering the notion of the collection and collecting, in parallel to the notion of exhibition, she considers also the history of museum, as an institution which historically was established after the exhibitions, ${ }^{34}$ but which in many aspects is associated with them.

When considering the relationship of the exhibitions and museum one must start from the fact that, parallel to the emergence and development of exhibitions, there comes to forming of the institution of museum as the places having many common characteristics with these manifestations. ${ }^{35}$ The museums, by means of exhibitions, displayed the collections of objects which classified, described and continuously reconstructed the world, materializing the ideas about what that world looked like, how it was established and who controls it. ${ }^{36}$ As newly formed institutions, museums, galleries and exhibitions had a key role in forming the modern state as educative and civilization achievement, and thus in the mid $18^{\text {th }}$ century forming and development of such type of institutions and events became the priority of all national states in their infancy, since they have proved as rather successful cultural catalysts as regards recruiting and participation of the citizens in the public life. ${ }^{37}$

As already mentioned, since they emerge and develop parallel with the institution of museum, the question of the exhibitions format can be discussed parallel with consideration of the institution of museum (and even the theatre) in a certain number of cases. ${ }^{38}$ The interdependence of the exhibitions and museums is primarily reflected in that the exhibitions became the medium through which the importance of the material collected within the museum was shown. ${ }^{39}$ Within the museum, it is the exhibitions which show the collected material and directly by exhibitions organizations the museums affirm their social role of communication with the public becoming incorporated in the contemporary society. ${ }^{40}$

\section{Exhibitionary Complex: The Exhibitions among the Discipline, Surveillance and Spectacle}

In order to make a more precise determination of the historiographical development of exhibitions and their theoretical basis, this part of the paper discusses the notion of the "exhibitionary complex" which had a great influence upon forming and development of the phenomenon of exhibitions. Exhibitionary complex is a part of the theoretical starting point derived by Tonny Bennett with the intention to explain the phenomenon of establishment of exhibitionary manifestations, museums and galleries all over Europe during 
the $18^{\text {th }}$ and the $19^{\text {th }}$ centuries. Through this notion, Bennett attempts to explain the manner in which modern state, by organizing knowledge at the exhibitions and in the museums, tried to achieve a new way of influence on the populace. ${ }^{41}$ Trying to define this complex notion, Bennett says that the exhibitionary complex comprises, first of all, the reform of the artistic expression which should have provided the new way of spreading power of the ruling élite. He determined the entire process as emergence of the exhibitionary complex and says that establishment of museums, galleries and multitude of exhibitions after 1871 represented a symptom of the state involment in the new social circumstances. Bennett specifies the manifestations emerged following the 1851 London World Exhibition as a new form of "softer" violence implemented by the state and in determining the notion of exhibition he refers to the theories of Michel Foucault - primarily to the notion "carceral archipelago" - in the modern state. On the basis of these theories, Bennett concludes that the modern state tried to "win the heart" of the people by wide spreading and presentation of knowledge, first of all, by establishing museums and exhibitions which should have quenched the thirst of the public for exhibitions, whereas on the other part they made it possible for the state to take a new regulatory and promotional role of the mediator and provider within the field of knowledge. ${ }^{42}$

Bennett, therefore, adopts Foucault's theoretical framework on the relationship of the knowledge and power to explain the idea of power which is associated with the exhibitions. Bennett says that exhibitions, owing to their form and position, have become "the means for spreading the message of power within society" ${ }^{43}$ As stated by Bennett, following Foucault, the new forms of display which emerged in the middle of the $19^{\text {th }}$ century were part of the process of origination of the new concept of knowledge, while at the same time they were also a part of the process of forming the audience which would receive that knowledge. Bennett further states that the institutions within which the systems of displaying were emerging were included in the transfer of the objects and people from the closed private space of collections, within which they were earlier exposed to the limited audience, into the open and public space of display. Through time, these institutions have become the means for registering and expansion of the state power through populace, which was subjected to the new discipline by the state. ${ }^{44}$ In order to explain this statement, Bennett uses Foucault's idea on the relationship between the power and panopticon, and "through the lessons about power - the power of arranging things and people for public display - says that the new forms of display aimed at allowing the people to acquire knowledge, en masse rather than individually, not only as the objects of cognition and the objects of knowledge but also as their subjects". ${ }^{45}$ 
The important role in construction of the system of exhibitions as an integral part of the new power structures in the $19^{\text {th }}$ century was played by the museum displays, panoramas and world exhibitions. The visual machinery of the world exhibitions developed in this period helped the exhibits to be established as metanarratives by means of which public opinion was formed in a particularly controlled manner. Since the popularity of the world exhibitions, museums and fairs in the $19^{\text {th }}$ century was extremely high and that the number of visitors grew from year to year, these sites appeared to be the places of vision and exchange, where an individual could become familiar with the achievements of the global progress. ${ }^{46}$ The World Exhibition held in London in 1851 marked the beginning of such trend, within which the aim was to attain dominance over knowledge and public by means of the exhibition. The Crystal Palace, which was built for the purpose of holding this exhibition, inverted the principle of panopticom, focusing the visitors' attention to the multitude of displayed objects. ${ }^{47}$ In such context, the exhibitions showed "the tendency of the society to be altogether shown as spectacle in all its integral parts and as a totality"48, as well as the ambition towards dominance over totality, which was even more obvious in the concept of the international exhibitions, which during the period of their greatest popularity were the place within which the past, the present and the future of the world were shown through the objects and works displayed.

The studies of the exhibitions from the period of the $19^{\text {th }}$ century emphasized the influence of the economic factor upon the organization and concept of the exhibitions themselves, particularly emphasizing the transformation of showing the machines, techniques, technological and industrial processes or the finished products and art objects into materialized indicators of progress. ${ }^{49}$ However, it is not sufficient to analyze the exhibitions only through the economic aspect. As the museums and fairs had great influence upon the contemplation of the visitors themselves (psychological effect), there emerged the issue of the physical presence of the visitors within the exhibition, hence there came to the need for greater physical - architectural interventions within the very manifestations. There came to the need, as stated by Foucault, to think about a different physical frame - architecture/space which would be built not only to be seen (as in luxuriously decorated palaces) or with which to observe the exterior space (geometry of the fortress), but to provide the inner, defined and detailed control, to influence those being inside the building. The architecture whose role would be to transform the individuals, to influence those who are found within, to provide the influence on their behavior. ${ }^{50}$ 


\section{EXHIBITIONS AND ARCHITECTURE:}

\section{THE RELATIONSHIP OF DISCURSIVE DEPENDENCE}

The relationship of exhibitions and architecture was determined from the beginning by the fact that the exhibitions were held within the gallery space, the museum or other exhibition area. Therefore, the exhibitions were predetermined by spatial framework within which they were staged, while architecture was thus the part of every exhibition: as place, framework, and boundary within which these events took place. ${ }^{51}$ However, the question arises about what happens when an exhibition has the aim to show architecture? What is the relation in this case? How to show architecture, which was the framework and took place within that architecture in the form of exhibition?

Having in mind the importance of exhibitions, as events within which affirmation (or denial) of certain value system and architecture happened, not only as an object of articulation of social reality, but also as an active subject which participates in the construction of that reality, the relationship between the exhibition and architecture can be defined as one of discursive dependencies where the exhibition as an institutional framework and architecture as a discipline intertwines in a unique project of mutual formalization and official establishment. Discursive practice of architecture presentation within exhibitions was a way of presenting architecture as a developmental process related to and dependent on social reality which that process reflects. Based on that, the history of exhibitions of architecture, perceived as a representative sample of social systems and their cultural values, became the subject matter that had the aim to perceive ways in which architecture exhibition as a discipline, and cultural and institutionalized practice, as well as the text and theory were involved in the structure, i.e. the content of social reality (identity).

\section{Architecture Exhibitions}

From the historical viewpoint, the active collection of the material associated with architecture could be followed since the $13^{\text {th }}$ century when the first collections of architectural designs and plans were formed, ${ }^{52}$ and when the intensive collection activity began with final aim to collect and organize the data on architecture. With the development of exhibitions, as an independent medium, through time the conditions were created to organize manifestations within which the collected material on architecture would be displayed and presented. ${ }^{53}$ Although it can be said that organization of the architecture exhibitions possesses a certain tradition, it was only in the mid-1960s that 
the true significance of the exhibitions as the new typological category was exposed $^{54}$, which had a great influence upon the establishment of the historical and formal-stylistic narratives in history and theory of architecture. According to Barry Bergdoll, the curator of the Department of Architecture and Design within the Museum of Modern Art in New York, the architecture exhibitions are a phenomenon which is more often linked to the period of the early $20^{\text {th }}$ century. Although the architectural designs were shown at salons and in galleries even before the emergence of the first museums at the end of the $18^{\text {th }}$ century, the exhibition as a phenomenon experienced its full potential in this period ${ }^{55}$, when the majority of museums became interested in including architecture in their programs ${ }^{56}$, whereby the new possibilities were created for actualization of architecture as social activity which this way was attributed a new critique aspect. ${ }^{57}$ Taking into account the relationship between architecture and society, museum represented an ideal place to construct a desirable image of architecture, through the narrative of the exhibition organization and display of architecture, through their interaction and the relationship towards a broader cultural and social context. ${ }^{58}$

\section{Performativity of the Museum Institutions}

In a more detailed determination of the relationship among museum, architecture and exhibition, as mutually dependent categories, it is essential to determine the meaning of the notion of performativity ${ }^{59}$ of the museum institution, which Jelena Stojanović defines as "a type of critique methodology consisting of the analysis of action of one institution in the process of subject forming and which is understood as analyses of the ritual, the act that is repeated and makes the basis of the activity of each institution." ${ }^{\prime 60}$ According to her statements, when determining performativity, first of all the physical frame of the given institutions (architecture, building style, placement of the exhibits, organization of the placement, etc.) is analyzed following which "the textual proposal of the given institution" ${ }^{\prime \prime 1}$ is analyzed - for which she says that is always determined by the art history discipline and that it can be determined in two ways: as an approach through a certain period (or periods) or is of a monograph character.

The notion of the performativity of museum institutions is also dealt with by Carol Duncan in her study on the role of the first public museums, who determines performativity as an experience occurring as part of the "disciplinary and disciplining strategy which museum visitor must comply with in order to enter and stay in the museum building". ${ }^{62}$ According to her, by accepting these 
rules, the visitor "becomes part of the panoptic situation and 'knows' very well that he/she is observed, monitored, controlled. He/she knows if he/she should make a mistake he/she would be punished, expelled from the game, namely shown the door of the museum". Museum performativity has an effect upon the visitor to enter the spirit of one's role, fully equating himself/herself to the ideological expectations of the institutions as a superb subject of the performance. Besides, Carol Duncan sees the role of performativity also in that the museums were from the beginning a part of the "status play of the vicarious consumption", which Veblen terms the vicarious or indirect consumption ${ }^{63}$, and the new social order. ${ }^{64}$ Duncan believes that the museums are "discursive devices" formed after the French Revolution and that they were established "as some type of objectification or as agents of spreading, wide spreading the postrevolutionary rhetoric in the process of creation of this ideology subject." ${ }^{\prime 65}$

\section{Architecture and Exhibitions}

Through time architecture exhibitions started to imply a wide spectrum of multifarious activities, whose task was to present ideas and authorial positions of both the architects themselves, and curators' who organized (curated) them. In the course of historical development of these manifestations, diverse types of architecture exhibitions emerged and developed, which are primarily distinguished by artifacts, according to what they had as the subject of display, as well as per the manner in which they displayed those exhibits.

In considering these questions and the current status of the architecture exhibitions, Carson Chan ${ }^{66}$, the architect and curator, attempts to define what an exhibition actually represents and whether its typological classification as part of architecture is possible. Based on the statements that architects design forms in space, as well as that the exhibitions should also exits as forms in space, Chan concludes that thereby exhibitions are defined as architecture, i.e. as one of the fields of interest of architecture and architects. ${ }^{67}$ In order to define the relationship between exhibitions and architecture as better as possible, while explaining his standpoint Chan poses a question: "What happens when the exhibition shows architecture? How is it possible, that in this case architecture is both the object and the context (place) of presentation at the same time?"68 Based on this difference, i.e. the relationship of architecture, as an object of presentation and the place of presentation, through time, diverse approaches in architecture presentation within exhibitions were developed. While each individual exhibition presented diverse aspects of the discipline, these variations indicated to the rather essential problem in displaying architecture - 
the question of representation. ${ }^{69}$ The importance of the exhibitions as means of communication in architecture is associated with presentation (representation). Thus the displays - the images of architecture, even though they are not architecture per se, have acquired the properties of the displayed art exhibits, and so the sketches and drawings have become important exhibits per se, unrelated to architecture they represented.

Since most often it is not possible to display architecture in its actual size (One on One) the question is how and what is the best way of representing architecture at exhibitions. ${ }^{70}$ And in spite of the individual examples where for the requirements of the exhibition the entire buildings, or their parts, in their full size, were displayed, in the majority of cases the architecture exhibitions imply architecture representation, in the form of drawings, photographs, models, videos, and recently also by means of the new media and technologies. In order to come up with an answer how within exhibitions architecture is represented, Carson Chan says that the concept of representation through drawings (floor plans, cross-sections, façade) started by exhibiting the representations of architecture, and not the architecture itself, at the École des Beaux-Arts within the reform of the educational process in the 19th century, where there came to the change in the way architecture is taught and studied ${ }^{71}$ - which initiates also the changes in the manner of architecture representation from the spatial models to the drawings and perspective presentations. ${ }^{72}$ Namely, the exhibitions were organized so that students could present their designs at the end of each part of the educational cycle they completed at school. Similar system of evaluation by displaying at exhibitions existed in Bauhaus school, where the exhibitions had the same purpose and status and were the place within which representation of the objects was used as the way of promotion and self-affirmation of the architectural ideas. In brief, although the École des Beaux-Arts and Bauhaus helped in establishing and determination of the basic directives for architecture displaying (which remained even until the present day within a great number of schools of architecture), unlike certain exhibitions today, the exhibitions organized within these educational institutions almost never used this medium as the experience of architectural expressions, but more as the event and place for representation of the concepts and ideas originated within the process of architects education.

Since they were dually determined as part of the professional activities of the architects and as part of the institutional activities, the architecture exhibitions created a unique opportunity for the insight and understanding of the architectural profession, architects, architecture and the processes guiding 
it. This statement has proved to be true particularly if the thesis is taken that the cultural and art production, building industry, architecture and urbanism can be "read" as an expression, apologia, but also as the critique of the social and political reality in which they originated ${ }^{73}$, as well as that the exhibitions are considered places of public display which are most often exposed to the direct evaluation of the public. By superimposing architecture, which is the real product of the multifold connection with the society, as an exhibit, and the exhibition, as the place of inclusion of that exhibit in the contemporary society, a complex field of mutual influences, interactions, constructing and value denoting between architecture and exhibitions is obtained. Within that field, the exhibition functions as an independent form of diffusion of culture, which is the result of intentions, aspirations, wishes and (im)possibility of wider circle of participants: curators, authors, financiers, politicians, and emerges through the process of professional - artistic, but also scientific/research work on work-out of the theme (specified or elective) and the collection of material, theoretical organization of the exhibition concept and finally its establishment in the chosen space. As a relatively new activity within the art and architecture history, the practice of exhibition organization had a great significance and influence upon the architecture discipline as place where architects are promoted as authors ${ }^{74}$, then as the experimental polygon and as an institution by means of which new ideas in architecture, art and society in general were promoted and propagated.

Another important insight in exhibitions is in the form of institutional framework for propagating new social values, particularly when the exhibitions function in symbiosis with other "discursive devices" - such as, for instance, museums. The example of this insight is the already mentioned Museum of Modern Art in New York and modern, i.e. international architecture. In the text "Modernism and Museum: The Dialectics of Performativity" (Модернизам и музеј: Дијалектика перформативности) Jelena Stojanović says that modernism, its emergence and development are closely related to the formation of the first museums, museum institutions, museology discipline and art history. According to her, the origination and existence of the museum institution can be taken as a proof that modernism is defined as discourse "which builds, constructs different (modern) relation of permanence, memories, time, historicity but also the subject." Further on in the text, while deliberating the history of the Museum of Modern Art in New York and its role and significance, she / Jelena Stojanović writes about the exhibition which was held in 1932 organized by Alfred Barr, Philip Johnson and Henry Russell Hitchcock and about its influence on architecture history. The exhibition in question was "Modern architecture: International exhibition" which later on was colloquially re- 
named as International style and which had great influence on modernism acceptance and practice in the U.S.A. ${ }^{75}$ Besides this exhibition, at the same place sixty years later, Philip Johnson together with Mark Wigley curated the exhibition "Deconstruvistic Architecture" which this time "was a call" to critique modernist canon. ${ }^{76}$ These two architecture exhibitions, according to Ljiljana Blagojevic, "mark two lines or two ends of the modern architecture criticism discourse, whereas the former translates and thus canonizes and institutionalizes the modern, and the latter displaces , transforms, de-canonizes, de-configures and deinstitutionalizes it. ${ }^{77}$ Both exhibitions, as later on have been proved, had a great significance for architecture and its history. The first exhibition, first of all, as place of the "translation of the modern architecture itself" into International style, and the other as place where the position of the deconstructivist architects was institutionalized. ${ }^{78}$

At the end of the $20^{\text {th }}$ and the beginning of the $21^{\text {st }}$ century there came to the significant changes in view of the type and manner of displaying exhibits in architecture exhibitions. Photographic narratives which dominated at the exhibitions until the 1970s were replaced with contemporary media. Within the exhibitions, increasingly more often the original drawings, documents and transcripts were presented, so that the exhibition again actualized the question of historical archives. ${ }^{79}$ However, although the exhibitions had the task to expose the mentioned documents, very often those documents acquired a new historical interpretation. Discursive exhibition frame determined by the curator and the exhibition location determined also the type and manner of interpretation.

\section{CONCLUSION}

As it had already been noted in this and other researches of exhibitions, as temporally and spatially restricted phenomena, not only do they produce what should be accepted as public opinion, but they often constitute public opinion and represent its reflection. Having in mind this fact and the idea that modern society often finds itself through media and visual representation, the relationship among exhibition, architectural practice, and social events is further complicated. In the given research, the exhibitions were shown as a place of production and propagation of ideas of architecture and their accompanying catalogues as propaganda and educational instruments of exhibition. Generally speaking, exhibitions were considered independent forms of cultural diffusion, i.e. a coherent, systematized whole created as a result of intentions, aspirations, desires and possibilities of the meeting of participants (curators, authors, financiers) created through the process of professional and artistic work on the treatment of the subject and collection of materials. 
During this research of the mentioned exhibitions, the emphasis was on comparative analysis and contextualization of historical developmental process in architecture, culture and society of the $20^{\text {th }}$ century, whose general perception was associated with the Western culture and formally fragmented replications of the process on the "outskirts" and "edges", ${ }^{80}$ and their impact on contemporary socio-political and cultural situation. The aim was to use this approach for avoiding historical favoring of works and to start perceiving objects from temporally broader and disciplinary-critical objective perspective. By re-examining the exhibits and materials, the practice of interpreting certain phenomena exclusively by the standards of its time was prevented, as well as the attempt of historiographic canonization of the latest tendencies in architecture. 2011., http://koperseminar.pbworks.com/w/page/6815898/Papers

5 The above mentioned objects were part of the early court collections, the Renaissance cabinets of curiosity, encyclopedic art chambers and later on in the course of the $18^{\text {th }}$ century they became part of the newly established museums. Ljiljana Gavrilović, O politikama, identitetima i druge muzejske priče (Beograd: Etnografski institut SANU, 2009), 13

$6 \quad$ Martha Ward, „What's Important About the History of Modern Art Exhibitions?," in Thinking about Exhibition, ed. Reesa Greenberg, Sandy Nairne, and Bruce W. Ferguson (New York: Routledge, 1996), 454. 
Ward, „What)s Important About the History of Modern Art Exhibitions?,“ 460.

Ibid.

Ivo Maroević, „Izložba kao oblik muzejske komunikacije,“ Osječki zbornik 21 (1994): p.290.

Tony Bennett, „The Exhibitionary Complex,“ in Thinking about Exhibition, ed. Reesa Greenberg, Sandy Nairne, and Bruce W. Ferguson (New York: Routledge, 1996), p. 82.

Miško Šuvaković, „Ideologija izložbe: o ideologijama Manifeste,“ PlatformaSCCA 3 (2002), www.ljudmila.org/scca/platforma3/suvakovic.htm.

Ibid.

Ibid.

Ibid.

Reesa Greenberg, Bruce W. Ferguson, Sandy Nairne, „Introduction“ in Thinking about exhibitions, ed. Reesa Greenberg, Bruce W. Ferguson and Sandy Nairne (New York: Routledge, 1996), p. 2.

Benjamin, also sees the exhibition as the place within which there comes to blending of the mass public, process of industrial production and art i.e. as the precursor of the „cultural industry“ criticized by Teodor Adorno and the representatives of the Frankfurt School as the blend of commerce, spectacle and culture, in the middle fo the $20^{\text {th }}$ century. Dorothee Richter, „Exhibitions as cultural practices of showing-pedagogics, “ On curating 9 (2011): p.49, visited on January 15, 2010, http://www.on-curating.org/issue_09.php.

Svetlana Alpers, "The Museum as a Way of Seeing," in Exhibiting Cultures, ed. Ivan Karp and Steven D. Lavine (Washington, DC: Smithsonian Institution Press, 1991), p.26

Neal Curley, „Exhibition,“ visited on December 20, 2011, http://csmt.uchicago.edu/glossary2004/ exhibition.htm.

In this last case, so to say it concerns the gallery exhibition, however, the exhibition as the artwork does not represent only the summary of mutually autonomous exhibited artworks, but represents the overall environment as planned organized space in which the works are in conceptual, but also in visual art relationship. Dragana Vasiljević Tomić and Mariela Cvetić, ,Wohnlich, Venecijansko bijenale arhitekture 2008 - izložba i njena geneza, “ Arhitektura i urbanizam 24-25 (2009): p.22. Miško Šuvaković, Pojmovnik savremene umjetnosti (Zagreb: Horetzki, 2005), p.287

The art artifacts used to be exhibited even before this period, but never before that time their exhibition comprised such a wide circle of visitors.

The term "to exhibit" was formed in that same period, although at the beginning it did not exclusively relate to art and initially denoted the general display-showing in public - "to show"(something) in public or for the purpose of amusement or competition. Љиљана Гавриловић, Музеји и границе моћи (Београд: Књижара круг, 2011), p.29,

Martha Ward, „What's important about the history of modern art exhibitions?" in: Thinking about exhibitions, ed. Reesa Greenberg, Bruce W. Ferguson, Sandy Nairne (London, New York: Routledge, 1996), p. 454

Ibid.

Ibid.

The significance of the Salon can be spoken about by the data that following the establishment of the Paris Commune in 1871, a separate Ministry of Art was established one of whose task was just the reform of the Salon with an aim of dissolving the jury, in order to enable the artists themselves to deal with organization of the salon (even before this reform there were attempts to remove the jury influence and thus in 1863 the Salon of the Refused (Salon des Refusés) was established as an "alternative to discriminating policy of official jurying of the Salon". Such and similar practices continued even after the official dissolving of the jury at the Salon and resulted in a great number of "renegaded" Salon institutions "which have even survived to date as an expression of the democratic pluralism. Ivana Mance,,,Model salonske izložbe, “ Zarez 242 (2008), accessed/visited November 20, 2011, http://www.zarez.hr/pages/242/vizualna5.html.

According to Elsner and Cardinal) the science on classification is "the veritable mirror of our opinion, its changes are the best guide through the history of perception. Гавриловић, Музеји и границе моћи, р.28. 
Љиљана Гавриловић, О политикама идентитета и друге музејске приче, р.12 Lewis Kachur, Displaying the Marvelous (Cambridge, Massachusetts: The MIT Press, 2001), p. 68 Љиљана Гавриловић, О политикама идентитета и друге музејске приче, р. 12

Forming of modern museums started parallel with forming of the European national states. The British Museum was formed in 1753, and the Central Art Museum in Louvre in 1793. The museums, as institutions, grew out from former court collections, Renaissance cabinets of curiosities and encyclopedic kunstkamera. Ibid. p. 14.

First of all, this here implies the necessity of the public display, i.e. the existence of the public who both the museums and exhibitions were intended for as creators of broader, contextualized images of culture. Љиљана Гавриловић, Музеји и границе моћи, p. 30.

Ibid., p. 28.

Ibid., p. 32 .

Љиљана Гавриловић, Култура у излогу: ка новој музеологији (Београд: Етнографски институт САНУ, 2007), p. 54.

Museums represent complicated mechanisms consisting of numerous elements, with different goals and methods of work. Within the museum there are numerous activities going on which are directed towards the problems of scientific researches, exhibition organization, preservation or educational programs.

Ibid., p. 55.

Tonny Bennett, The Birth of the Museum: History, Theory, Politics (London: Routledge, 1995), p.63. Bennett's explanation of the notion in one part is focused on the development of the events in the Victorian England where colonialism played a great part in the reform of the artistic expression. He writes about the reception of the applied arts from India at the World Exhibition in London in 1851. In this example Bennett describes the exhibitionary complex as a combination of science, amusement and spectacle which made it possible that at the exhibition in London the colonial subjects were perceived from the scientific angle, and that it represented the method by means of which the colonial state presented to the public other people and in that way made the impression upon its own populace in the metropolis. Tony Bennett, „The Exhibitionary Complex,“ in Thinking about Exhibition, ed. Reesa Greenberg, Sandy Nairne, and Bruce W. Ferguson (New York: Routledge, 1996), p. 82.

Марина Симић, „Вид и виђење- режими знања и апропријација других у етнографским музејима и етнографском филму,“Гласник Етнографског института САНУ 58 (2010): p. 88. Симић, „Вид и виђење- режими знања и апропријација других у етнографским музејима и етнографском филму,“р..90.

Bennett, „The Exhibitionary Complex,“p. 85.

The exhibitions retained their preference as the place of presentation and exchange of knowledge as far as the 1930s. Although the number of visitors started to decline at the beginning of the twentieth century, with the emergence of the new techniques of representation, such as film, some other places took over the preference and began to replace the world fairs and exhibitions.

Panopticon was conceived as a place where everyone could be seen whereas the Crystal Palace was conceived as the place where everyone was able to see. Architectural innovation of the Crystal Palace implied such relation between the visitors and exhibits where everyone could "see" everything, however, there were places where everyone could be seen. Such relations within the Crystal Palace made it possible to combine within it the principles of spectacle and surveillance. Jasna Galjer, EXPO 58 i jugoslovenski paviljon Vjenceslava Richtera (Zagreb: Horetzky, 2009), p. 100 .

Within those exhibitions progress was understood to be collective national achievements coordinated by the capital.

Bennett, „The Exhibitionary Complex,“p. 87.

In this case most often the architectural elements do not represent the boundaries of the exhibitionary space but the exhibition space was constructed by the critics, curators, audience and other participants of the exhibition. 
The pioneer architecture exhibitions were most often organized within the museums of the applied art or within the educational institutions and professional associations of architects which has conditioned a specific context within which the exhibitions existed. Such exhibition context, which was organized within the museum or the educational institution, often determined the exhibition as the place of narrative, aimed at education of the audience. Phyllis Lambert, „The Architectural Museum: A Founder's Perspective,“" The Journal of the Society of Architectural Historians 58: 3 (1999): p. 308.

Although the importance of collecting the material associated with architecture was recognized quite early, such collections only relatively late, only in the 1970s, experienced their recognition as the basis of the new institution of the Architectural Museum. The formal recognition of the significance of those collections happened in 1979 in Helsinki when the fifteen newly formed institutions formed the International Confederation of Architectural Museums - ICAM. Since then the members of that Confederation have grown in number so that nowadays the Confederation numbers over 100 members, among which there are museums, archives, foundations, libraries. Source: http://www.icam-web.org/about.php. the Society of Architectural Historians 58: 3 (1999): p. 316.

Barry Bergdoll, „Curating History,“ The Journal of the Society of Architectural Historians 57: 3 (1999): p. 257.

Among them is also the Museum of Modern Art in New York, which under the management of Alfred Barr and Philip Johnson began to deal more seriously with the issues of architecture display. Although the architecture exhibitions organized within the museums as per their scope, form and contents were multifarious, their influence upon the process of architecture deliberation was unique. Namely, by means of exhibitions the importance of architecture and its relation towards society and the individual was presented as well as the process of re-defining the role of architects and their manner of action within the field of this discipline.

Although the institution of museum was of great importance for the architecture exhibitions and for positioning the architecture within the field of representational practices, it here implies less the physical frame, and more the narrative structure, within the frame of which the question of selection of exhibits, harmonization, size and medium in fact a system of coordinates which make mapping of a certain historical period possible.

Performativity as a critique category has a wide spectrum of meanings, in this case the definitions made by Carol Duncan and Jelena Stojanovic will be used.

Јелена Стојановић, „Модернизам и музеј: Дијалектика перформативности,“ Зборник Народног музеја- Историја уметности XVIII-2 (2007): p.472

Ibid.

Carol Duncan, Civilizing rituals: Inside public art museums (Lodnon: Routledge, 1995), p. 7.

For defining the notion of vicarious or indirect consumption see: Thorstein Veblen, The Theory of the Leisure Class: An Economic Study of Institutions (New York: B. W. Huebsch, 1918). Visited February 15, 2012. http://oll.libertyfund.org/?option=com_staticxt\&staticfile=show.php\%3Ftitle= $1657 \&$ chapter $=142967 \&$ layout $=$ html\&Itemid $=27$

Namely, in support of this statement the study of Brendon Taylor is cited, who within the frame of the study on British art museums and analysis of their role in forming the universal subject states the importance i.e. the function of dressing when visiting a museum, as one of the extremely efficient forms of social selection. Brendon Taylor, Art fot the Nation: Exhibitions and the London Public 1747-2001 (New Brunswick: Rutgers University Press, 1999).

According to Carol Duncan, based on their role, as influential, important and socially present institution with a precise social role, the museums have determined the twentieth century as ,the museum century".

Carson Chan is an architect, critic and independent curator dealing with the researches into the relationship of architecture and its relation to the exhibiting techniques. In the course of his career he has organized numerous exhibitions, workshops and lectures on this topic. More about the author himself and his theoretical and practical standpoints can be seen at: http://www.carsonchan.net/. 
Carson Chan, „How is architecture exhibited? What is an architecture exhibition?,“ Domus, September 17, 2010, http:/www.domusweb.it/en/architecture/ exhibiting-architecture-show-donttell//.

Ibid.

The notion of presentation or representation has a wide meaning depending on the context within which the given notion is considered. The very notion present-represent permeates political, aesthetic, metaphysical, historical, religious, epistemological order in such way that it becomes the object of reflection which is constitutive for each of these orders. In this order the interpretations of "representation" are possible in which it denotes the image presented and placed in front of the eyes, before the sensual and spiritual view. More broadly viewed, it is possible to associate the word "representation ,with the idiomatic expressions such as "to represent', "to be represented", etc. Петар Бојанић, Политичко представљање (Београд: Службени гласник, 2010), p. 7.

There were different examples: from the display of the parts or entire buildings in real size at the "Interbau" exhibition, within the International Building Exhibition in Berlin in 1957, as far as presenting the drawings and perspective displays at the exhibition in the Museum of Modern Art in New York in 1932.

Namely, in this period there came to the changes in the concept of architects education, from the trade to academic model, which implied the change on all levels of the educational process and their ultimate outcomes. The manner of evaluation of the students " work also changed and exhibitions were introduced as the place where the students represented the results of their work. Paul P. Cret, ,The Ecole des Beaux-Arts and Architectural Education,” The Journal of the American Society of Architectural Historians 1:2 (1941). Ibid.

Vladimir Kubet, Olga Carić i Dušan Ristić.’Izložbe Verkbunda - čitanja rukopisa modernizma danas," Arhitektura i urbanizam 28 (2010): p. 22

Illustrating the importance of exhibitions for the architect as the author Wallis Miller in the essay "Mies and Exhibitions" which deals with the work and exhibitions of Mies van der Rohe, writes about the exhibitions at which Mies designed, in which he participated and which he benefited from. In the text she indicates to the importance of these manifestations, as places of experiments and promotions, for defining Mies' author's approach in architecture. Wallis Miller,,Mies and Exhibitions, “ in Mies in Berlin, ed. Terrence Riley and Barry Bergdoll (New York: The Museum of Modern Art, 2001), 538. odjecima, ur. Petar Bojanić (Beograd: Institut za filozofiju i društvenu teoriju, 2005), 90. Ibid. 89

Ibid.89.

Within this exhibitions the works of the seven authors were presented: Bernard Tschumi, Peter Eisenman, Frank Gehry, Reem Koolhaas, Daniel Libeskind, Coop Himmelblau and Zaha Hadid group. Ibid. 91

Cohen, Jean-Louis. 'Exhibitionist Revisionism: Exposing Architectural History, The Journal of Architectural Historians, vol. 58, no. 3, 1999/2000, 320. 
Allwood, John. The Great Exhibitions: 150 years. London: ECL Exhibition Consultants Ltd, 2001. Altiser, Luj. Ideologija i državni ideološki aparati. Loznica: Karpos, 2009.

Benett, Tony. “The Ehxibitionary Complex,” New Formations 4 (1988): pp.73-102.

Black, Mischa. Exhibition design. London: The Architectural Press, 1951.

Blagojević, Ljiljana. „Dekonstruktivistička arhitektura n'existe pas,” u Glas i Pismo: Žak Derida u odjecima, ur. Petar Bojanić, str. 89-95. Beograd: Institut za filozofiju i društvenu teoriju, 2005.

Blagojević, Ljiljana."Metodske, konceptualne i sadržinske osnove reprezentacije prakse arhitektonsko-urbanističkog projektovanja i teorije savremene arhitekture," Arhitektura $i$ urbanizam 24-25 (2009): str. 15-18.

Bak-Mors, Suzan. Svet snova i katastrofa: Nestanak masovne utopije na Istoku i Zapadu. (2000) Prevod Aleksandra Kostić. Beograd: Beogradski krug. 2005.

Beatriz Colomina, Privacy and Publicity: Modern Architecture as Mass Media. Cambridge, Mass.: MIT Press, 1994.

Benjamin, Valter. O fotografiji i umetnosti. Prevod Jovica Aćin. Beograd: Kulturni centar Beograd, 2006.

Galjer, Jasna. EXPO 67 i jugoslavenski paviljon Vjenceslava Richtera. Zagreb: Horetzky, 2009. 
Гавриловић, Љиљана. Култура у излогу: ка новој музеологији. Београд: Етнографски институт САНУ, 2007.

Гавриловић, Љиљана. О политикама, идентитетима и друге музејске приче. Београд: Етнографски институт САНУ, 2009.

Gavrilović, Ljiljana. Muzeji i granice moći. Beograd: Knjižara krug, 2011.

Greenhalg, Paul. Ephemeral Vistas: The Expositions Universelles, Great Expositions and the World Fairs, 1851- 1939. Manchester: Manchester University Press, 1988.

Greenhalg, Paul. "Education, Entertainment and Politics: Lessons from the Great International Exhibitions." u The New Museology, ur. Peter Vergo, str. 74 -98. London: Reaktion Books Ltd, 1989.

Greenhalg, Paul. The moder Ideal: The Rise and Collapse of Idealism in the Visual Arts from the Enlightenment to Postmodernism. London: V \& A Publications, 2005.

Greenberg, Reesa, Bruce W. Ferguson and Sandy Nairne, ed., Thinking about Exhibitions. London: Routledge, 1996.

Гројс, Борис. Уметност утопије.(2003) Београд: Логос, 2011.

Groys, Boris. „The Museum in the Age of Mass Media,” Manifesta Journal: Journal of Conteporary Curatorship 1 (2003): p. 32-41.

Gutschow, Kai K., „From Object to Installation in Bruno Taut's Exhibit Pavilions,” Journal of Architectural Education (2006): pp. 63-70.

Duncan, Carol. Civilizing Rituals: Inside Public Art Museum. London: Routledge, 1995.

Karp, Ivan, ed. Museum Frictions: Public culture/ Global Transformations. London: Duke University Press, 2006.

Kubet, Vladimir, Olga Carić i Dušan Ristić.”Izložbe Verkbunda - čitanja rukopisa modernizma danas,“" Arhitektura i urbanizam 28 (2010): str.21-28.

Leatherbarrow, David.“The Craft of Criticism,” Journal of Architectural Education (2009): pp.2021.

Levy, Aaron and William Menking. ed. Architecture on Display: On the History of the Venice Biennale of Architecture. London: AA Publications, 2011.

Lorimer, Rolend. Masovne komunikacije: komparativni uvod. Beograd: Clio, 1998.

Maroević, Ivo. „Izložba kao oblik muzejske komunikacije,“Osječki zbornik 21 (1994): str. 289298.

Miller, Wallis. „Mies and Exhibitions, “ in Mies in Berlin, ed. Terence Riley,and Barry Bergdol, pp. 338-349. New York: The Museum of Modern Art, New York, 2001.

O'Doherty, Brian. Inside the white cube: The Ideology o Gallery Space. Santa Monica: The Lapis Press, 1976.

Sabatino, Michelangelo. "Space of Criticism: Exhibitions and the Vernacular in Italian Modernism," Journal of Architectural Education (2009): pp.35-52.

Симић, Марина. „Вид и виђење: режими знања и апропријација других у етнографским музејима и етнографском филму,“ Гласник Етнографског института САНУ 58 (2010): стр. $85-99$.

Stojanović, Jelena. „Модернизам и музеј: Дијалектика перформативности,“ Зборник Народног музеја- Историја уметности XVIII-2 (2007): стр. 47-483.

Sherman, Daniel J., and Irit Rogoff, ed. Museum culture: Histories, Discourses, Spectacles. Menneapolis: University of Minnesota Press, 1994.

Тодић, Миленка. Фотографија и пропаганда. Бања Лука: ЈУ Књижевна задруга, 2005.

Tomić-Vasiljević, Dragana, i Mariela Cvetić."Wohnlich, Venecijansko bijenale arhitekture 2008 izložba i njena geneza,“ Arhitektura i urbanizam 24-25 (2009): str. 19-24.

Hall, Stuart, ed. Representation: Cultural representations and signfying practices. London: Sage Publications, 1997.

Hyes, Michael K. ed. Architecture Theory since 1968. New York: MIT Press, 1998.

Hičkok-Džonson. Internacionalni stil. (1932) Prevod Ivana Trbojević. Beograd: Građevinska knjiga, 1989. 
Hensel, Michael., Hight, Christopher. And Menges. Achim. Space Reader: Heterogeneous Space in Architecture. West Sussex: John Wiley \& Sons Ltd, 2009.

Hooper-Greenhill, Eilean. Museums and the Shaping of Knowledge. London: Routledge, 1992. Crimp, Douglas. On the Museum's Ruins. London: The MIT Press, 1993.

Čarapić, Ana, Sanja Simonović, i Božidar Manić, „, Arhitektura - granice, manifesti, utopijske vizije - osvrt na jedanaesto Venecijansko bijenale,“ Arhitektura i urbanizam 24-25(2009): str. 7-14.

Šuvaković, Miško. i Erjavec, Aleš. Figure u pokretu-Savremena zapadan estetika, filozofija $i$ teorija umetnosti. Beograd: Atoča, 2009.

Шуваковић, Мишко. Постмодерна: (73. појма). Београд, Народна књига/Алфа, Библиотека Појмовник, 1995.

Wesemal, Pieter van. Architecture of Instruction and Delight. A socio- historical analysis of World Exhibitions as a didactic phenomenon (1798-1851 


\section{STRATEGIJE IZLAGANJA I PREZENTACIJE ARHITEKTURE KAO IZLOŽBENE FORME \\ (sa osvrtom na izlagačke prakse u Srbiji \\ nakon 2000. godine)}

\section{Milorad Mladenović}

Ovaj tekst bavi se postojećim i mogućim modalitetima i strategijama izlaganja i prezentacije savremene arhitekture i to u specifičnim izlagačkim uslovima (galerijskim ili muzejskim prostorima ili u kontekstu javnog prostora), bez namere da se pitanje prezentacije posmatra u svim njenim aspektima s obzirom na složenost i sve okolnosti širine ove teme. Težište ovog teksta postavljeno je na nivo istraživanja odnosa između realnog modela i njegove prezentacije ili na različitim načinima interpretacije projektovanog modela u kontekstu njegove moguće realizacije ili neke njegove posebne programske ili utopijske društvene funkcije. Takođe, težište teksta bazirano je na analizi medijskih praksi prezentacija ideja i koncepata u arhitekturi, kao i na mogućnostima da se arhitektura prezentuje kao profesionalna, umetnička i društvena praksa putem tih medija.

U posebnom delu ovog teksta biće predstavljena praksa izlaganja i prezentacije srpske arhitekture nakon 2000. godine kroz analizu sistema i oblika izlaganja u postojećim društvenim i kulturnim uslovima od značaja za oblast arhitekture, a na osnovu prethodno datih analiza.

KLJUČNE REČI: IZLAGANJE ARHITEKTURE, MODELI IZLAGANJA, MEDIJI IZLAGANJA, MODELI KOMUNICIRANJA, PROSTOR IZLAGANJA, IZLAGANJE ARHITEKTURE I UMETNOSTI, IZLAGAČKE PRAKSE U SRBIJI

\section{IZLOŽBENI SINDROM: ARHITEKTURA KAO EKSPONAT}

\section{Mladen Pešić}

U ovom istraživanju, izložbe se razmatraju prevashodno kao institucije, odnosno kao mesto interakcije različitih identiteta kroz izbor eksponata, njihovu prezentaciju, prostornu dispoziciju i kroz odabir i upotrebu pratećih tekstova. Ovako postavljen kontekst istraživanja pokušaće da odgovori na pitanje na koji način je moguće konstruisati istoriju izložbi - zaboravljenih, često bez dovoljno dokumentacije ili zapisa o njima. Pored toga, preispitaće se na koji način su izložbe pomogle u stvaranju i promovisanju ideje arhitekture tokom 20-og veka, preklapajući se sa smenama diskursa, širih filozofskih rasprava i tehnoloških inovacija. 